\title{
Improvement of Student Learning Outcomes Through The Implementation Of The Problem Based Learning Model For Class IV Elementary School
}

\author{
Ita Laila Puji Rahmawati \\ SDN Pedurungan Lor 01 Semarang \\ Italaila16@gmail.com
}

\section{Article History \\ accepted 14/11/2020}

approved 21/11/2020

\begin{abstract}
This research is a classroom action research (PTK) which consists of two cycles. This PTK has two cycles in one cycle, there are four stages, namely planning, implementing, observing and reflecting. The research subjects were students of grade IV A SDN Pedurungan Lor 01 Semarang, Central Java with a total of 31 students. Data collection techniques using test and non-test techniques. The assessment instrument uses item items and observations of the scoring rubric. The results showed that the application of the Problem Based Learning learning model can improve student learning outcomes in Theme 4 Various Classes IV A SDN Pedurungan Lor 01 Semarang, this is evidenced by the learning outcomes in cycle I, namely 14 students out of 31 students or $45 \%$, while students who completed as many as 17 students from 31 students or 55\%. In cycle II, in the initial conditions according to the background of the research, there were 22 students out of 31 students or $71 \%$ who had not yet completed it. In cycle II, there were 7 students out of 31 students or $23 \%$ who had not completed, while 24 students out of 31 students or $77 \%$ who had completed it. This means that student learning outcomes increase from cycle I to cycle II. The conclusion of this study is that using the Problem Based Leraning learning model can improve student learning outcomes in Theme 4 Various Occupations of class IV A SDN Pedurungan Lor 01 Semarang.
\end{abstract}

Keywords: learning model, problem based learning, learning outcomes

\section{Abstrak}

Penelitian ini merupakan penelitian tindakan kelas (PTK) yang terdiri dari dua siklus. PTK ini ada dua siklus dalam satu siklus ada empat tahapan yaitu perencanaan, pelaksanaan, pengamatan dan refleksi. Subyek penelitian adalah siswa kelas IV A SDN Pedurungan Lor 01 Semarang Jawa Tengah dengan jumlah siswa 31 anak. Teknik pengumpulan data dengan teknik tes dan non tes. Adapun instrumen penilaiannya menggunakan butir-butir soal dan pengamatan rubrik penilaian. Hasil penelitian menunjukkan bahwa penerapan model pembelajaran Problem Based Learning dapat meningkatkan hasil belajar siswa pada Tema 4 Berbagai Pekerjaan Kelas IV A SDN Pedurungan Lor 01 Semarang, hal ini dibuktikan dari hasil belajar pada siklus I yaitu siswa yang belum tuntas sebanyak 14 siswa dari 31 siswa atau $45 \%$, sedangkan siswa yang tuntas sebanyak 17 siswa dari 31 siswa atau $55 \%$. Pada siklus II, Pada kondisi awal sesuai dengan latar belakang penelitian, siswa yang belum tuntas sebanyak 22 siswa dari 31 siswa atau $71 \%$. Pada siklus II, siswa yang belum tuntas sebanyak 7 siswa dari 31 siswa atau $23 \%$, sedangkan siswa yang tuntas sebanyak 24 siswa dari 31 siswa atau $77 \%$. Ini artinya hasil belajar siswa meningkat dari siklus I ke siklus II. Kesimpulan dari penelitian ini adalah menggunakan model pembelajaran Problem Based Leraning dapat meningkatkan hasil belajar siswa pada Tema 4 Berbagai Pekerjaan kelas IV A SDN Pedurungan Lor 01 Semarang. Kata kunci: model pembelajaran, problem based learning, hasil belajar

Social, Humanities, and Education Studies (SHEs): Conference Series https://jurnal.uns.ac.id/shes

p-ISSN 2620-9284

e-ISSN 2620-9292 


\section{PENDAHULUAN}

Upaya untuk meningkatkan mutu pendidikan nasional yang terus menerus dilakukan oleh pemerintah maupun masyarakat, misalnya pengembangan kurikulum nasional dan lokal, peningkatan kompetensi guru, pengadaan media pembelajaran seperti buku dan alat pembelajaran, perbaikan sarana dan prasarana pendidikan di sekolah. Untuk itu penulis merasakan pengembangan pembelajaran perlu ditingkatkan baik dari segi perencanaan, penggunaan model, alat peraga maupun kemampuan guru dalam mengembangkan kurikulum serta kemampuan sikap percaya diri dan penguasaan konsep pembelajaran dengan subtema Indahnya Kebersamaan.

Pemilihan model pembelajaran yang ditetapkan dalam pembelajaran tematik terpadu pada kurikulum 2013 antara lain : project based learning, problem based learning, dan discovery learning dapat mengaktifkan siswa serta menyadarkan siswa bahwa muatan pelajaran tematik tidak selalu membosankan. Dilihat dari hasil ulangan harian, sebagian besar nilai Kelas IV SDN Pedurungan Lor 01 Semarang masih di bawah Kriteria Ketuntasan Minimal (KKM) yaitu 75.

Berdasarkan pengamatan yang peneliti lakukan di SDN Pedurungan Lor 01 Semarang pada kegiatan pembelajaran belum menggunakan model pembelajaran yang menarik, sehingga masih banyak siswa yang tidak memahami materi yang diajarkan. Penggunaan media yang dilakukan guru juga belum maksimal, sehingga berpengaruh terhadap hasil belajar siswa.

Saat ditanya mengenai materi yang baru disampaikan, sebagian dari mereka tidak dapat menjawab, jika guru memberi kesempatan untuk bertanya mengenai kesulitan tentang materi pelajaran, tidak ada yang bertanya bahkan kelas menjadi hening. Hal tersebut membuktikan bahwa aktifitas belajar mereka masih sangat rendah. Mengamati permasalahan tersebut, peneliti akan menggunakan model pembelajaran Problem Based Learning dalam proses pembelajaran untuk meningkatkan kualitas pembelajaran agar hasil belajar siswa meningkat menjadi lebih baik. Model pembelajaran yang tepat, pembelajaran dapat berlangsung secara aktif, efektif, inovatif, dan menyenangkan.

Berdasarkan latar belakang di atas, maka akan dilakukan perbaikan proses dan hasil pembelajaran maka penulis memilih model Problem Based Learning memiliki kelebihan : pengetahuan yang diperoleh melalui strategi ini sangat ampuh karena menguatkan pengertian, ingatan dan transfer. Dengan menggunakan model Problem Based Learning diharapkan siswa dapat meningkatkan hasil belajar. Melalui penelitian tindakan kelas dengan judul Peningkatan Hasil Belajar Siswa Pada Tema 4 Berbagai Pekerjaan Melalui Penerapan Model Problem Based Learning di SDN Pedurungan Lor 01 Semarang Kelas IV Semester 1 Tahun Pelajaran 2020/2021.

Menurut Kamdi (2007: 77), "Problem Based Learning (PBL) merupakan model kurikulum yang berhubugan dengan masalah dunia nyata siswa. Masalah yang diseleksi mempunyai dua karakteristik penting, pertama masalah harus autentik yang berhubungan dengan kontek sosial siswa, kedua masalah harus berakar pada materi subjek dari kurikulum". Terdapat tiga ciri utama dari model Problem Based Learning (PBL).

Pertama, problem based learning merupakan rangkaian aktivitas pembelajaran, artinya dalam implementasi PBL ada sejumlah kegiatan yang harus dilakukan siswa, siswa tidak hanya mendengar, mencatat, kemudian menghafal materi pelajaran, tetapi melalui model problem based learning (PBL) siswa menjadi aktif berpikir, berkomunikasi, mencari dan mengolah data, dan akhirnya membuat kesimpulan. Kedua, aktivitas pembelajaran diarahkan untuk menyelesaikan masalah. Problem based learning ini menempatkan masalah sebagai kata kunci dari proses pembelajaran. Artinya tanpa masalah pembelajaran tidak akan mungkin bisa berlangsung. Ketiga, pemecahan masalah menggunakan pendekatan berpikir secara ilmiah. 
Menurut Nurhadi (2004: 65) "Problem based learning adalah kegiatan interaksi antara stimulus dan respons, merupakan hubungan antara dua arah belajar dan lingkungan". Lingkungan memberi masukan kepada siswa berupa bantuan dan masalah, sedangkan sistem saraf otak berfungsi menafsirkan bantuan itu secara efektif sehingga yang dihadapi dapat diselidiki, dinilai, dianalisis, serta dicari pemecahannya dengan baik. PBL merupakan sebuah pendekatan pembelajaran yang menyajikan masalah konstektual sehingga merangsang siswa untuk belajar. PBL merupakan suatu model pembelajaran yang menantang siswa untuk belajar, bekerja secara berkelompok untuk mencari solusi dari permasalahan dunia nyata. Masalah ini digunakan untuk mengikat siswa pada rasa ingin tahu pada pembelajaran yang dimaksud.

Berdasarkan uraian mengenai PBL di atas, dapat disimpulkan bahwa PBL merupakan pembelajaran yang menghadapkan siswa pada masalah dunia nyata (real world) untuk memulai pembelajran. Masalah diberikan kepada siswa, sebelum siswa mempelajari konsep atau materi yang berkenaan dengan masalah yang harus dipecahkan. Dengan demikian untuk memeahkan masalah tersebut siswa akan mengetahui bahwa mereka membutuhkan pengetahuan baru yang harus dipelajari untuk memecahkan masalah yang diberikan.

Berdasarkan sintak tersebut, langkah-langkah pembelajaran Problem Based Learning (PBL) yang bisa dirancang oleh guru adalah sebagai berikut:

Tabel 1. Langkah Pembelajaran PBL

\begin{tabular}{|c|c|c|}
\hline LANGKAH KERJA & AKTIVITAS GURU & AKTIVITAS PESERTA DIDIK \\
\hline $\begin{array}{l}\text { Orientasi peserta } \\
\text { didik pada masalah }\end{array}$ & $\begin{array}{l}\text { Guru menyampaikan } \\
\text { masalah yang akan } \\
\text { dipecahkan secara } \\
\text { kelompok. Masalah yang } \\
\text { diangkat hendak-nya } \\
\text { kontekstual. Masa-lah bisa } \\
\text { ditemukan sendiri oleh peserta } \\
\text { didik melalui bahan bacaan } \\
\text { atau lembar kegiatan. }\end{array}$ & $\begin{array}{l}\text { Kelompok mengamati dan } \\
\text { memahami masa-lah yang } \\
\text { disampaikan guru atau yang } \\
\text { diperoleh dari bahan bacaan } \\
\text { yang disarankan. }\end{array}$ \\
\hline $\begin{array}{l}\text { Mengorganisasikan } \\
\text { peserta didik untuk } \\
\text { belajar. }\end{array}$ & $\begin{array}{l}\text { Guru memastikan setiap } \\
\text { anggota } \\
\text { memahami tugas masing- } \\
\text { masing. }\end{array}$ & $\begin{array}{l}\text { Peserta didik berdiskusi dan } \\
\text { membagi tugas untuk mencari } \\
\text { data/bahan-bahan/alat } \\
\text { yang diperlukan untuk } \\
\text { menyelesaikan masalah. }\end{array}$ \\
\hline $\begin{array}{l}\text { Membimbing } \\
\text { penyelidikan individu } \\
\text { maupun kelompok. }\end{array}$ & $\begin{array}{l}\text { Guru memantau keterlibatan } \\
\text { peserta didik dalam } \\
\text { pengumpulan data/ bahan } \\
\text { selama proses } \\
\text { penyelidikan. }\end{array}$ & $\begin{array}{l}\text { Peserta didik melakukan } \\
\text { penyelidikan } \\
\text { (mencari data/referensi/sumber) } \\
\text { untuk bahan diskusi kelompok. }\end{array}$ \\
\hline $\begin{array}{l}\text { Mengembangkan dan } \\
\text { menyajikan hasil karya. }\end{array}$ & $\begin{array}{l}\text { Guru memantau diskusi dan } \\
\text { membimbing pembuatan } \\
\text { laporan sehingga karya setiap } \\
\text { kelompok siap untuk } \\
\text { dipresentasikan. }\end{array}$ & $\begin{array}{l}\text { Kelompok melakukan diskusi } \\
\text { untuk menghasil-kan solusi } \\
\text { pemecahan masalah dan } \\
\text { hasilnya } \\
\text { dipresentasikan/disajikan dalam } \\
\text { bentuk karya. }\end{array}$ \\
\hline $\begin{array}{l}\text { Menganalisis dan } \\
\text { mengevaluasi proses } \\
\text { pemecahan masalah. }\end{array}$ & $\begin{array}{l}\text { Guru membimbing presentasi } \\
\text { dan mendorong kelompok } \\
\text { memberikan penghargaan }\end{array}$ & $\begin{array}{l}\text { Setiap kelompok melakukan } \\
\text { presentasi, kelompok yang lain } \\
\text { memberikan apresiasi. }\end{array}$ \\
\hline
\end{tabular}




\begin{tabular}{lll}
\hline LANGKAH KERJA & \multicolumn{1}{c}{ AKTIVITAS GURU } & \multicolumn{1}{c}{ AKTIVITAS PESERTA DIDIK } \\
\hline & $\begin{array}{l}\text { serta masukan kepada } \\
\text { kelompok lain. Guru bersama } \\
\text { peserta didik menyimpulkan } \\
\text { materi. }\end{array}$ & $\begin{array}{l}\text { Kegiatan dilanjutkan dengan } \\
\text { merangkum/ membuat } \\
\text { kesimpulan sesuai dengan } \\
\text { masukan yang diperoleh dari } \\
\text { kelompok lain. }\end{array}$ \\
\hline
\end{tabular}

Menurut Nana Sudjana (2008) mengemukakan penilaian hasil belajar mengisyaratkan bahwa hasil belajar sebagai objek yang menjadi sasaran penilaian. Hasil belajar sebagai objek penilaian pada hakikatnya menilai penguasaan siswa terhadap tujuan-tujuan intruksional, karena rumusan tujuan intruksional menggambarkan hasil belajar yang harus dikuasai siswa berupa kemampuankemampuan siswa setelah menerima atau menyelesaikan pengalaman belajarnya. Hasil belajar sebagai objek penilaian pada hakikatnya menilai penguasaan siswa terhadap tujuan-tujuan intruksional, karena rumusan tujuan intruksional menggambarkan hasil belajar yang harus dikuasai siswa berupa kemampuankemampuan siswa setelah menerima atau menyelesaikan pengalaman belajarnya. Sedangkan Bloom, dkk (dalam Asep Heri Hernawan, 2009) menggolongkan hasil belajar menjadi tiga, yaitu kognitif, afektif, dan psikomotor. Dari beberapa pengertian hasil belajar, penulis menyimpulkan bahwa hasil belajar adalah tanda atau bukti yang diperoleh siswa yang berguna untuk mengukur kemampuan siswa setelah selesai pembelajaran. Tujuan yang hendak dicapai dalam penelitian ini adalah untuk mengetahui model pembelajaran Problem Based Learning dalam meningkatkan hasil belajar siswa pada Tema 4 Berbagai Pekerjaan di Kelas IV di SDN Pedurungan Lor 01 Semarang.

\section{METODE}

Penelitian Tindakan Kelas (PTK) yang digunakan peneliti adalah jenis PTK kolaboratif. PTK kolaboratif yaitu kerja sama antara peneliti dengan teman sejawat, ide berasal dari peneliti dan yang melakukan tindakan adalah guru mata pelajaran tematik kelas IVA SDN Pedurungan Lor 01 Semarang di lakukan pada semester I. Unit penelitian adalah kelas IVA SDN Pedurungan Lor 01 Semarang. Penelitian ini dilaksanakan pada semester I tahun pelajaran 2020/2021. Subjek dalam penelitian ini adalah siswa kelas IV A SDN Pedurungan Lor 01 Semarang Jawa Tengah dengan jumlah siswa 31 anak. Teknik pengumpulan data yang dipakai dalam penelitian tindakan ini adalah teknik tes dan non tes yang terdiri dari: Tes berbentuk pilihan ganda, digunakan untuk mengukur kemampuan siswa setelah diberi strategi model pembelajaran Problem Based Learning. Non tes dalam penelitian ini berupa pengamatan implementasi RPP, pengamatan aktivitas siswa dan penilaian proses. Pengamatan implementasi RPP digunakan untuk mendapat data tentang pengajaran guru didalam kelas serta pengamatan keaktifan siswa, sehingga bisa dilihat di dalam pelaksanaan pembelajaran benar-benar sesuai dengan kondisi dan proses yang diharapkan. Pengamatan melalui diskusi dan presentasi dilakukan terhadap proses pembelajaran dengan menggunakan model pembelajaran Problem Based Learning. Dokumentasi digunakan untuk mendapatkan data tentang identitas dari siswa. Dalam hal ini data yang diperoleh adalah daftar siswa menonjol baik dari segi positif maupun negatifnya. Teknik analis data yang peneliti gunakan dalam penelitian untuk mengetahui tingkat keberhasilan belajar siswa kelas IVA SDN Pedurungan Lor 01 Semarang menggunakan model pembelajaran Problem Based Learning yaitu teknik deskriptif komparatif yakni teknik statistik dengan membandingkan skor antar siklus, persentase, mean, skor minimal, maksimal. 


\section{HASIL DAN PEMBAHASAN}

Penelitian yang telah dilakukan akhirnya diperoleh data-data yang dapat diuraikan sebagai berikut: Perencanaan Penelitian. Kegiatan yang dilakukan dalam tahapan ini adalah menyiapkan segala sesuatu yang diperlukan dalam melaksanakan skenario pembelajaran siklus I yang telah direncanakan. Kegiatan yang dilakukan antara lain: Membuat Rencana Pelaksanaan Pembelajaran (RPP) dengan materi Tematik Tema 4 Berbagai Pekerjaan. Menyiapkan lembar observasi (pengamatan) sebagai pedoman atas proses pembelajaran menggunakan video powerpoint. Menyusun soal tes untuk menilai peningkatan hasil belajar siswa terhadap materi yang diajarkan.

Pelaksanaan tindakan dilakukan 2 kali yaitu pada tanggal 2 dan 3 November 2020. Deskripsi pelaksanaan tindakan pembelajaran adalah sebagai berikut : Penerapan tindakan mengacu pada RPP yang dibuat. Dalam pelaksanaan pembelajaran dengan menggunakan model problem based learning meliputi beberapa tahap, yaitu: Guru mengkondisikan siswa sebelum pembelajaran dimulai dengan cara guru mengajak siswa berdoa menurut agama dan kepercayaan masing-masing. Guru menjelaskan tujuan pembelajaran. Guru menyampaikan apersepsi untuk memancing dan membangkitkan pengetahuan yang telah dimiliki siswa. Guru menjelaskan secara singkat kepada siswa mengenai subtema Jenis-jenis Pekerjaan. Guru menjelaskan cara mengerjakan LKPD. Pemberian penghargaan kelompok. Kemudian guru membagikan lembar tugas siswa yang dikerjakan secara individu. Siswa bersama guru menyimpulkan materi yang telah dipelajari. Guru memberi motivasi dan penguatan kepada siswa.

Pertemuan kedua. Penerapan tindakan mengacu pada RPP yang dibuat. Dalam pelaksanaan pembelajaran dengan menggunakan model problem based learning meliputi beberapa tahap, yaitu: Guru mengkondisikan siswa sebelum pembelajaran dimulai dengan cara guru mengajak siswa berdoa menurut agama dan kepercayaan masing-masing. Guru menjelaskan tujuan pembelajaran. Guru menyampaikan apersepsi untuk memancing dan membangkitkan pengetahuan yang telah dimiliki siswa. Guru menjelaskan secara singkat kepada siswa mengenai subtema Jenis-jenis Pekerjaan. Guru menjelaskan cara mengerjakan LKPD. Pemberian penghargaan kelompok. Kemudian guru membagikan lembar tugas siswa yang dikerjakan secara individu. Siswa bersama guru menyimpulkan materi yang telah dipelajari. Guru memberi motivasi dan penguatan kepada siswa.

Berdasarkan latar belakang penelitian ini, hasil pembelajaran tematik tema 4 pada siswa kelas 4A yang berjumlah 31 siswa, sebelum menggunakan model pembelajaran Problem Based Learning, rata - rata yang diperoleh adalah 61,61. Siswa yang mencapai KKM adalah $29 \%$ dan siswa yang belum mencapai KKM adalah $71 \%$, sehingga dapat diartikan KKM belum tuntas, karena KKM dianggap tuntas adalah jika mencapai minimal $75 \%$. Hasil observasi yang dilakukan oleh observer selama jalannya kegiatan pembelajaran dan mengamati hasil evaluasi pada akhir kegiatan siklus pertama belum berhasil karena siswa yang tuntas hanya 17 siswa dari 31 siswa. Siswa yang sudah tuntas baru mencapai 55\%. Hasil belajar pada siklus I mengalami peningkatan dibandingkan dengan keadaan awal yang disajikan pada latar belakang masalah. Hasil tes awal siswa yang tuntas mencapai $29 \%$, sedangkan pada hasil evaluasi siklus I siswa yang tuntas mencapai 55\%. Hal ini menunjukkan ada peningkatan hasil belajar siswa sebesar $26 \%$. Dari deskripsi di atas menunjukkan bahwa hasil rata-rata kelas meningkat pada siklus I, namun belum dikatakan berhasil dalam pembelajaran Tema 4 karena siswa yang tuntas (KKM) belum mencapai $75 \%$. Berdasarkan hal tersebut, maka masih diperlukan perbaikan pembelajaran dengan 
media yang sama pada Siklus II. Berdasarkan hasil tes awal dan evaluasi siklus 1 tersebut, dapat dilihat presentase ketuntasan belajar siklus 1 sebagai berikut :

Tabel 1. Persentase Ketuntasan Belajar Siklus I

\begin{tabular}{clcccc}
\hline No & \multicolumn{1}{c}{ Uraian } & \multicolumn{2}{c}{ Siswa yang Tuntas } & \multicolumn{2}{c}{ Siswa Belum Tuntas } \\
\hline 1 & $\begin{array}{l}\text { Kondisi Awal (sesuai } \\
\text { dengan keadaan pada latar } \\
\text { belakang) }\end{array}$ & 9 & $29 \%$ & 22 & $71 \%$ \\
2 & Siklus I & 17 & $55 \%$ & 14 & $45 \%$ \\
\hline
\end{tabular}

Tabel di atas dapat dijelaskan siswa yang belum tuntas belajar adalah sebagai berikut : Pada kondisi awal sesuai dengan latar belakang penelitian, siswa yang belum tuntas sebanyak 22 siswa dari 31 siswa atau $71 \%$. Pada siklus 1, siswa yang belum tuntas sebanyak 14 siswa dari 31 siswa atau 45\%. Sedangkan siswa yang tuntas belajar adalah sebagai berikut : Pada kondisi awal sesuai dengan latar belakang penelitian, siswa yang tuntas sebanyak 9 siswa dari 31 siswa atau $29 \%$. Pada siklus 1 , siswa yang tuntas sebanyak 17 siswa dari 31 siswa atau 55\%. Berdasarkan tabel diatas dapat dibuat diagram batang hasil belajar siklus 1 sebagai berikut :

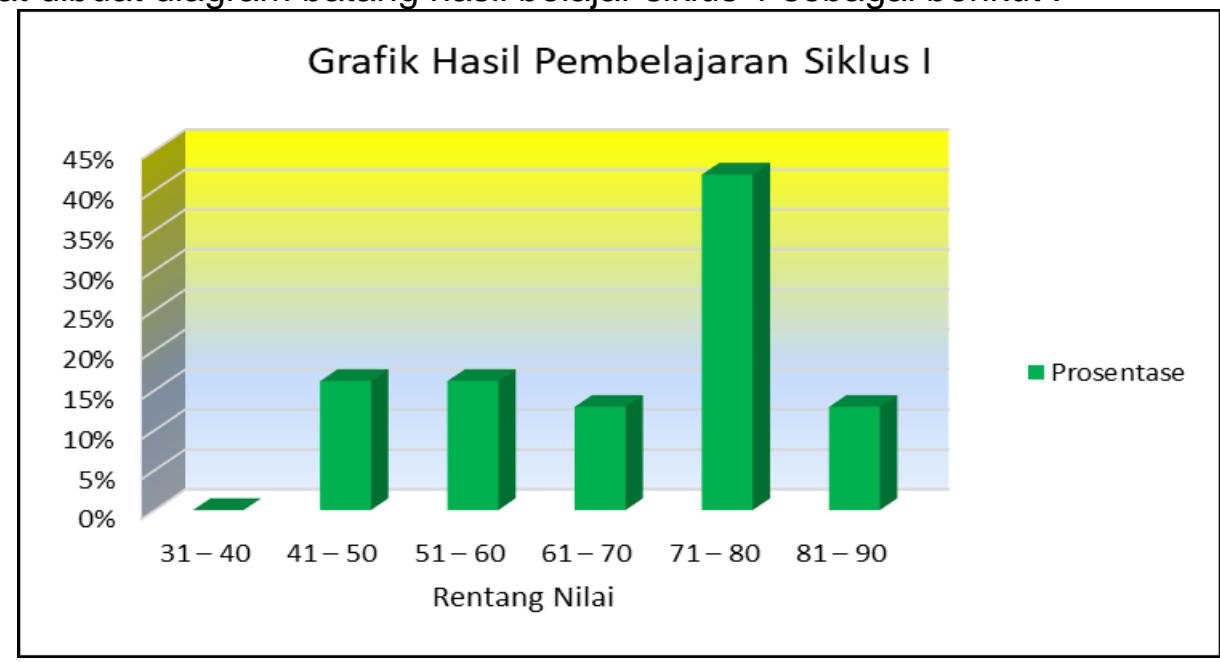

Gambar 1. Grafik ketercapaian hasil belajar siklus I

Siklus II penelitian yang telah dilakukan akhirnya diperoleh data-data yang dapat diuraikan sebagai berikut: Perencanaan Penelitian. Kegiatan yang dilakukan dalam tahapan ini adalah menyiapkan segala sesuatu yang diperlukan dalam melaksanakan skenario pembelajaran siklus I yang telah direncanakan. Kegiatan yang dilakukan antara lain: Membuat Rencana Pelaksanaan Pembelajaran (RPP) dengan materi Tematik Tema 4 Berbagai Pekerjaan. Menyiapkan lembar observasi (pengamatan) sebagai pedoman atas proses pembelajaran menggunakan video powerpoint. Menyusun soal tes untuk menilai peningkatan hasil belajar siswa terhadap materi yang diajarkan.

Pelaksanaan Tindakan. Dilakukan 2 kali yaitu pada tanggal 9 dan 10 November 2020. Deskripsi pelaksanaan tindakan pembelajaran adalah sebagai berikut : Pertemuan Pertama. Penerapan tindakan mengacu pada RPP yang dibuat. Dalam pelaksanaan pembelajaran dengan menggunakan model problem based learning meliputi beberapa tahap, yaitu: Guru mengkondisikan siswa sebelum pembelajaran dimulai dengan cara 
guru mengajak siswa berdoa menurut agama dan kepercayaan masing-masing. Guru menjelaskan tujuan pembelajaran. Guru menyampaikan apersepsi untuk memancing dan membangkitkan pengetahuan yang telah dimiliki siswa. Guru menjelaskan secara singkat kepada siswa mengenai subtema Jenis-jenis Pekerjaan. Guru menjelaskan cara mengerjakan LKPD. Pemberian penghargaan kelompok. Kemudian guru membagikan lembar tugas siswa yang dikerjakan secara individu. Siswa bersama guru menyimpulkan materi yang telah dipelajari. Guru memberi motivasi dan penguatan kepada siswa.

Pertemuan kedua. Penerapan tindakan mengacu pada RPP yang dibuat. Dalam pelaksanaan pembelajaran dengan menggunakan model problem based learning meliputi beberapa tahap, yaitu: Guru mengkondisikan siswa sebelum pembelajaran dimulai dengan cara guru mengajak siswa berdoa menurut agama dan kepercayaan masing-masing. Guru menjelaskan tujuan pembelajaran. Guru menyampaikan apersepsi untuk memancing dan membangkitkan pengetahuan yang telah dimiliki siswa. Guru menjelaskan secara singkat kepada siswa mengenai subtema Jenis-jenis Pekerjaan. Guru menjelaskan cara mengerjakan LKPD. Pemberian penghargaan kelompok. Kemudian guru membagikan lembar tugas siswa yang dikerjakan secara individu. Siswa bersama guru menyimpulkan materi yang telah dipelajari. Guru memberi motivasi dan penguatan kepada siswa

Hasil observasi yang dilakukan oleh observer selama jalannya kegiatan pembelajaran dan mengamati hasil evaluasi pada akhir kegiatan siklus kedua bisa dikatakan sudah berhasil karena siswa yang tuntas sebanyak 24 siswa dari 31 siswa. Dengan kata lain siswa yang tuntas sudah mencapai $77 \%$. Namun, meskipun ketuntasan sudah mencapai $75 \%$ masih diperlukan perbaikan karena masih ada 7 siswa yang nilainya di bawah KKM.

Hasil belajar pada siklus II mengalami peningkatan dibandingkan dengan siklus I. Hasil evaluasi siklus I siswa yang tuntas mencapai $55 \%$, sedangkan pada hasil evaluasi siklus II siswa yang tuntas mencapai $77 \%$. Hal ini menunjukkan ada peningkatan hasil belajar siswa sebesar $22 \%$. Dari deskripsi di atas menunjukkan bahwa hasil rata-rata kelas meningkat pada siklus II, dengan kata lain dapat dikatakan berhasil dalam pembelajaran Tema 4 karena siswa yang tuntas (KKM) sudah mencapai $75 \%$. Meskipun demikian, masih diperlukan perbaikan pembelajaran dengan media yang sama pada siklus III.

Berdasarkan hasil evaluasi siklus II tersebut, dapat dilihat presentase ketuntasan belajar siklus II sebagai berikut :

Tabel 2. Persentase Ketuntasan Belajar Siklus II

\begin{tabular}{|c|c|c|c|c|c|}
\hline \multirow[b]{2}{*}{ No } & \multirow[b]{2}{*}{ Uraian } & \multicolumn{2}{|c|}{ Siswa yang Tuntas } & \multicolumn{2}{|c|}{ Siswa Belum Tuntas } \\
\hline & & Frekuensi & Persentase & Frekuensi & Persentase \\
\hline 1 & $\begin{array}{l}\text { Kondisi Awal (sesuai } \\
\text { dengan keadaan pada } \\
\text { latar belakang) }\end{array}$ & 9 & $29 \%$ & 22 & $71 \%$ \\
\hline 2 & Siklus I & 17 & $55 \%$ & 14 & $45 \%$ \\
\hline 3 & Siklus II & 24 & $77 \%$ & 7 & $23 \%$ \\
\hline
\end{tabular}

Tabel di atas dapat dijelaskan siswa yang belum tuntas belajar adalah sebagai berikut : Pada kondisi awal sesuai dengan latar belakang penelitian, siswa yang belum tuntas sebanyak 22 siswa dari 31 siswa atau $71 \%$. Pada siklus I, siswa yang belum tuntas sebanyak 14 siswa dari 31 siswa atau 45\%. Pada siklus II, siswa yang elum tuntas sebanyak 7 siswa dari 31 siswa atau 23\% Sedangkan siswa yang tuntas belajar adalah sebagai berikut : Pada kondisi awal sesuai dengan latar belakang penelitian, siswa yang tuntas sebanyak 9 siswa dari 31 siswa atau 29\%. Pada siklus 1, siswa 
yang tuntas sebanyak 17 siswa dari 31 siswa atau 55\%. Pada siklus II, siswa yang tuntas sebanyak 24 siswa dari 31 siswa atau $77 \%$

Berdasarkan tabel diatas dapat dibuat diagram batang hasil belajar siklus II sebagai berikut :

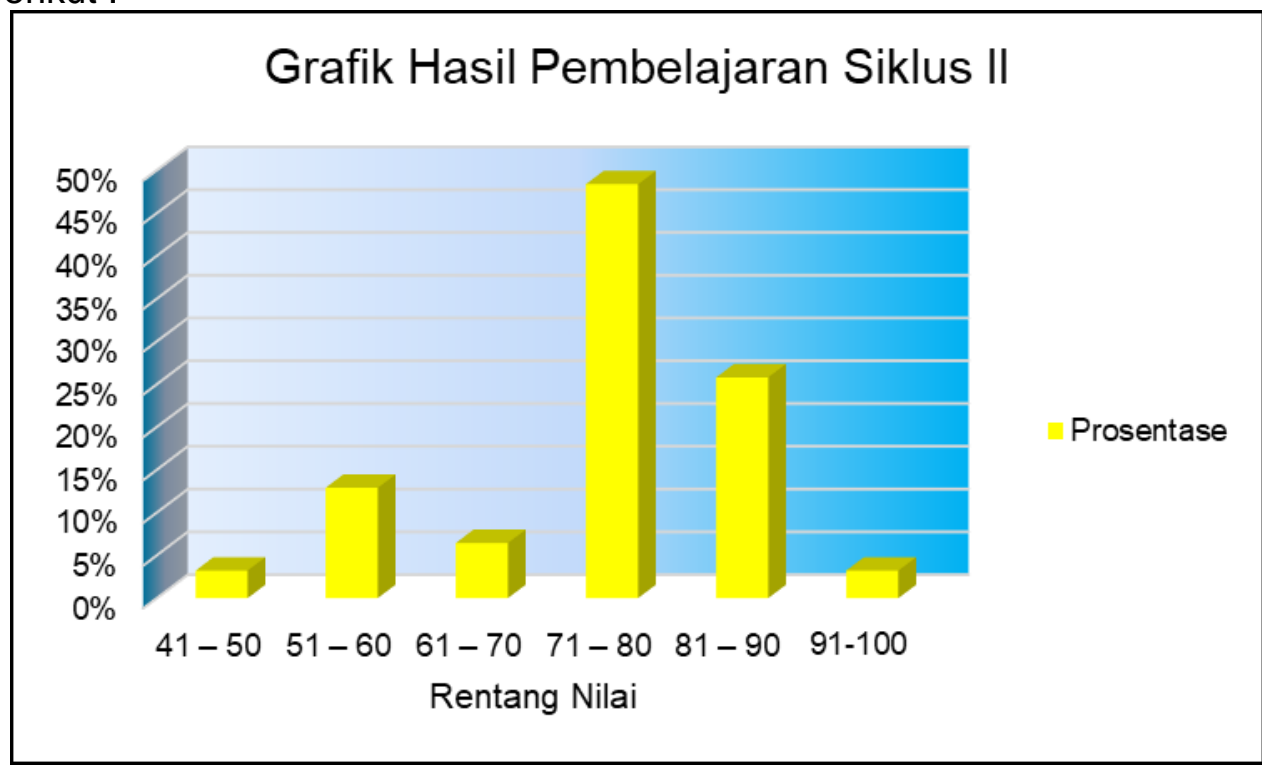

Gambar 2. Grafik hasil belajar siklus II

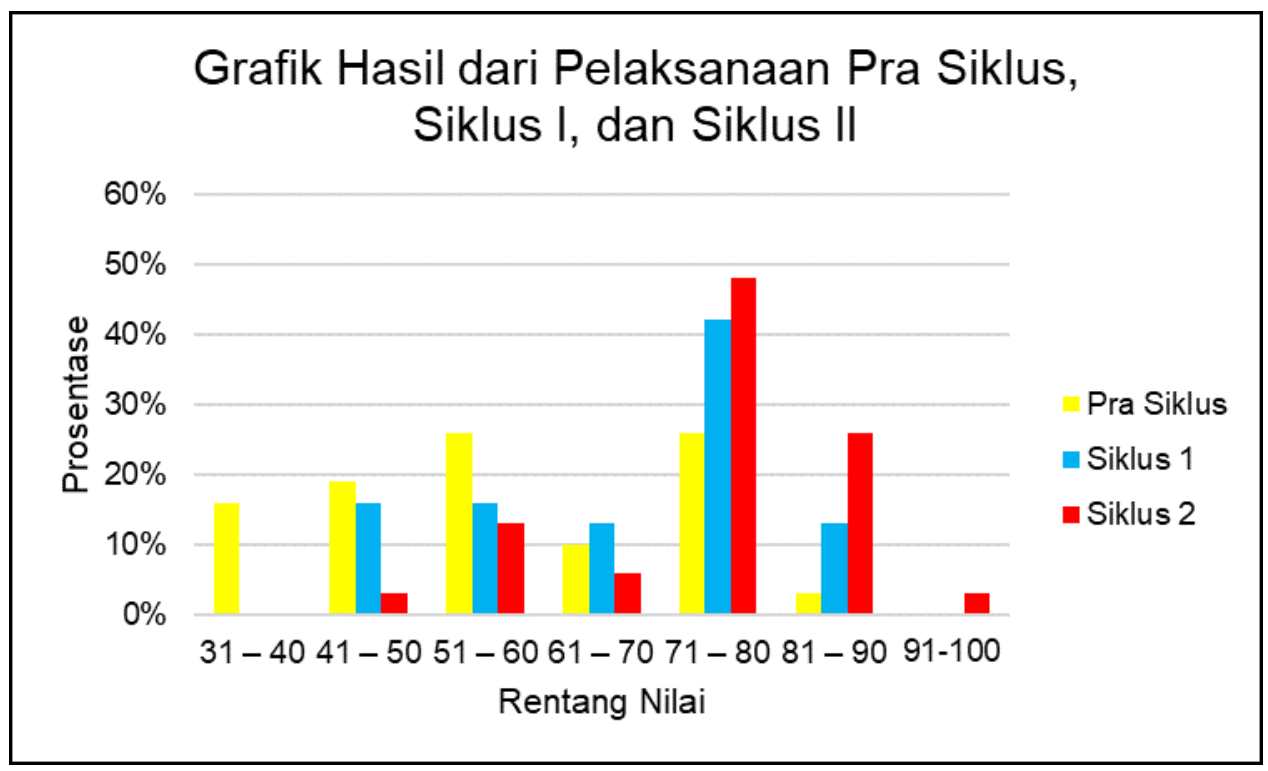

Gambar 3. Grafik perbandingan hasil belajar

\section{SIMPULAN}

Penggunaan model Problem Based Learning dapat meningkatkan hasil belajar siswa pada Tema 4 Berbagai Pekerjaan kelas IV A SDN Pedurungan Lor 01 Semarang, hal ini dibuktikan bahwa pada kondisi awal sesuai dengan latar belakang penelitian, siswa yang belum tuntas sebanyak 22 siswa dari 31 siswa atau $71 \%$. Pada siklus I diperoleh bahwa siswa yang belum tuntas sebanyak 14 siswa dari 31 siswa atau $45 \%$, sedangkan siswa yang tuntas sebanyak 17 siswa dari 31 siswa atau 55\%. Pada siklus II, siswa yang belum tuntas sebanyak 7 siswa dari 31 siswa atau $23 \%$, sedangkan siswa yang tuntas sebanyak 24 siswa dari 31 siswa atau $77 \%$. Ini artinya hasil belajar siswa meningkat dari siklus I ke siklus II. 
DAFTAR PUSTAKA

Arikunto, S. 2006. Metode Penelitian Kualitatif. Jakarta: Bumi Aksara

Anas Sudijono. 2006. Pengantar Statistik Pendidikan. Jakarta: PT. Grafindo Persada.

Darmadi. 2017. Pengembangan model dan metode pembelajaran dalam dinamika belajar siswa. Yogyakarta: CV Budi Utama.

Daryanto. 2013. Media Pembelajaran Peranannya Sangat Penting dalam Mencapai Tujuan Pembelajaran. Yogyakarta: Gava Media.

Hamalik, Oemar. 2001. Psikilogi Belajar dan Mengajar. Bandung : Sinar Baru Algensindo.

Hasan, M.lqbal. 2002. Pokok - pokok Materi Metodologi Penelitian dan Aplikasinya. Bogor: Ghalia Indonesia

Hidayatullah, M.F. 2009. Guru Sejati Membangun insane berkarakter kuat dan cerdas. Surakarta: Yuma Pustaka.

Wibowo Mungin, Edy. 2008. Kurikulum Tingkat Satuan Pendidikan Sekolah Dasar. Jakarta: Depdiknas.

Wijayanto, M. 2009. Tesis: Pengaruh Penerapan Model Problem Based Learning dan Cooperative Learning terhadap Prestasi Belajar Matematika Ditinjau dari Motivasi Belajar Siswa (Studi Eksperimen pada Siswa Kelas X Sekolah Menengah Atas Negeri Kabupaten Wonogiri Tahun Pelajaran 2008/2009. Surakarta: UNS. 